\section{Wilt Avoidance in St. Augustinegrass Germplasm}

\author{
Philip Busey \\ Fort Lauderdale Research and Education Center, Institute of Food and \\ Agricultural Sciences, University of Florida, 3205 College Avenue, Fort \\ Lauderdale, FL 33314
}

Additional index words. breeding, cultivar, drought, germplasm, resistance, turf, water, Stenotaphrum secundatum

\begin{abstract}
St. Augustinegrass [Stenotaphrum secundatum (Walt.) Kuntze] is less droughtresistant than other $\mathrm{C}_{4}$ grasses and frequently requires irrigation in lawns. The objectives of this study were to search for St. Augustinegrass germplasm having little wilting and to determine if minimal wilting under drought is associated with reduced canopy loss. St. Augustinegrass cultivars and breeding lines, representing polyploids $(2 n=27$ to 32$)$ and diploids $(2 n=18)$, were grown in sand soil and exposed to irrigation suspensions during seasonal droughts in three experiments. In the first experiment, during brief ( 3 to 14 day) irrigation suspensions, wilted area over 3 years was significantly less for polyploids (6\% of canopy) than for diploids $(23 \%)$. In the second experiment, during a permanent irrigation suspension, frequency of wilt was highest for diploids $(57 \%)$, least for African polyploids (27\%), and intermediate $(53 \%)$ for other polyploids. When rain resumed after 41 days of drought, allowing refoliation, canopy loss was $51 \%, 4 \%$, and $47 \%$ for diploids, African polyploids, and other polyploids, respectively. In the third experiment, during a permanent irrigation suspension, wilted area was $33 \%$ for 'Jade,' a diploid, which was more $(P \leq 0.05)$ than for the polyploid 'FX-10,' with a wilted area of $20 \%$. 'Floratam' and 'Bitterblue' were intermediate in wilted area, $28 \%$ and $25 \%$, respectively. When rain resumed after 18 days of drought, canopy loss was $58 \%$ and $56 \%$ for 'Jade' and 'Bitterblue,' respectively, which was more than for 'Floratam' and 'FX-10,' $11 \%$ and $6 \%$. Following permanent irrigation suspensions, canopy loss was closely associated with wilting, $r^{2}=0.88$ and 0.94 by the Gompertz nonlinear model. Because the sand soil had low water-holding capacity, the wet subsoil and shallow (1.35 $\mathrm{m}$ deep) water table may have been a source of water. Wilt-avoidant St. Augustinegrass may help reduce turfgrass water use.
\end{abstract}

St. Augustinegrass, an important turf of the tropics and warm humid regions, is less drought resistant than most other $\mathrm{C}_{4}$ turfgrasses (Beard, 1973). It has a higher water use rate than bermudagrass (Cynodon spp.) and zoysiagrass (Zoysia spp.) (Kneebone and Pepper, 1982) and frequently requires irrigation in lawns. St. Augustinegrass has relatively small leaf internal diffusive resistance (Johns et al., 1983); stomata do not substantially control evapotranspiration rate from a well-watered canopy. Ten St. Augustinegrass genotypes do not differ in evapotranspiration rates under wellwatered conditions in the field (Atkins et al. 1991), indicating that genotypic variability in external diffusive resistance (aerodynamic and

Received for publication 29 Jan. 1996. Accepted for publication 18 July 1996. Florida Agricultural Expt. Station Journal Series no. R-04961. This research was supported in part by the South Florida Water Management District. I am grateful for material support by Estech Branded Fertilizers, King Ranch Sod Farm, R \& D Sod Farms, and Sunbelt Services and for technical assistance by Barbara J. Center, Bonnie L. Coy, Rodrigo Moriones, Gerald Renick, and Mickey A. Stanaland. The cost of publishing this paper was defrayed in part by the payment of page charges. Under postal regulations, this paper therefore must be hereby marked advertisement solely to indicate this fact. canopy) may be negligible. Although water use evaluation has failed to identify drought resistant St. Augustinegrass genotypes, differences in wilting were noticed in St. Augustinegrass germplasm evaluated in the field. The objectives of this study were to search for St. Augustinegrass germplasm having reduced wilting and to determine if minimal wilting under drought is associated with reduced canopy loss.

\section{Materials and Methods}

Genotypes evaluated were vegetatively propagated St. Augustinegrass cultivars and breeding lines (FX- designations), the latter developed at the Fort Lauderdale Research and Education Center, Davie, Broward County, Fla. (Tables 1 and 2). Diploid $(2 n=18)$ breeding lines were crosses among Breviflorus and Longicaudatus races (Busey, 1986). Polyploid breeding lines were crosses among $2 n=30$ African introductions (Busey, 1990) and seedlings from 'Floratam' $(2 n \approx 32)$, whose pollen parents were probably polyploid African introductions. Plots were at Fort Lauderdale Research and Education Center. Soil was a Margate fine sand (siliceous, hyperthermic, Mollic Psammaquent), 94\% sand, 5\% silt, and $1 \%$ clay, with $\mathrm{pH} 7.2, \mathrm{P}$ at 41 and $\mathrm{K}$ at 13 $\mathrm{mg} \cdot \mathrm{Kg}^{-1}$, and $5.5 \%$ organic matter. To mea- sure soil moisture retention, access pits were excavated in St. Augustinegrass plots and 29$\mathrm{mm}$-diameter horizontal cores were removed at consecutive 50-mm depths down to $1 \mathrm{~m}$. This test was done twice, in Nov. 1988 and Apr. 1989, $24 \mathrm{~h}$ after saturating rain, and twice again, in Jan. 1989 and May 1989, following 9 or more days with $5 \mathrm{~mm}$ or less rain. Cores were weighed, dried at $60^{\circ} \mathrm{C}$, and reweighed. Percent water was calculated on the basis of soil dry weight, and cumulative water-holding capacity and soil moisture depletion (saturated vs. dry) were calculated, after correcting for soil bulk density. Rain was recorded within $300 \mathrm{~m}$ from the plots.

Wilted area during briefirrigation suspensions (Expt. 1). Twenty St. Augustinegrass genotypes (Table 1) were planted 18 Mar. 1986, replicated in eight complete blocks. Soil had been treated in Aug. 1985 with methyl bromide at $5.1 \mathrm{~g} \cdot \mathrm{m}^{-2}$. Plots were $4.6 \times 6.7 \mathrm{~m}$, planted with 24 prerooted sprigs. Plots were mowed at $65 \mathrm{~mm}$, about every 2 weeks. When plots were fully covered with St. Augustinegrass, 7 months after planting, each was divided into high- and low-fertilization halves, applied on a split-block basis every 2 months. The high fertilization split received $\mathrm{N}$ at $31 \mathrm{~g} \cdot \mathrm{m}^{-2} \cdot \mathrm{year}^{-1}$ in 1987 and 1988 , and at 15 $\mathrm{g} \cdot \mathrm{m}^{-2}$ in 1989 . The low fertilization split received $\mathrm{N}$ at $11 \mathrm{~g} \cdot \mathrm{m}^{-2} \cdot \mathrm{year}^{-1}$ in 1987 and 1988 , and at $5 \mathrm{~g} \cdot \mathrm{m}^{-2}$ in 1989 . Fertilizer analysis was $16 \mathrm{~N}-2 \mathrm{P}-7 \mathrm{~K}$, with micronutrients; $\mathrm{N}$ source was primarily ammonium nitrate. Stolons encroaching between plots were controlled with a nonselective herbicide, or pulled by hand. No broadcast herbicides were applied. Fire ants (Solenopsis invicta Buren) and southern chinch bugs (Blissus insularis) Barber, were treated on a spot basis. Except during irrigation suspensions, all plots were irrigated 18 $\mathrm{mm}$ during the night following daytime wilt in any plot. During 10 intervals from 1987 to 1989, irrigation was suspended, from 3 to 14 days, and plots were evaluated for wilted area, as a percentage of the canopy. The duration of irrigation suspensions was brief, and varied depending on weather, to avoid canopy loss. Viewed toward the sun, wilted portions of plots were grayish, and nonwilted portions were bright green. Wilt was verified by inspection of individual leaves, whose blades were either folded and curled (wilted) or turgid and open (nonwilted). For statistical analysis of wilted area, fertilization rate (high vs. low) was nested within blocks. Evaluation dates within years were pooled as repeated measures. Significant $(P \leq 0.05)$ interactions (e.g., genotype $\times$ year and genotype $\times$ fertilization) and nonhomogeneous variances (across years and fertilization rates) required separate comparisons for each fertilization $\times$ year combination. Years were also combined as repeated measures to provide an overall measure of wilted area.

Frequency of wilt and canopy loss from permanent irrigation suspension (Expt. 2). Twenty-five St. Augustinegrass genotypes (Table 2) were planted 12 Aug. 1987, replicated in eight complete blocks. Soil had been treated in July 1987 with methyl bromide at 
$5.1 \mathrm{~g} \cdot \mathrm{m}^{-2}$. Plots were $3.0 \times 4.1 \mathrm{~m}$, planted with 12 plugs, $110 \times 100 \mathrm{~mm}$, which had previously been grown under a uniform condition in trays. Plots were mowed at $67 \mathrm{~mm}$, about every 2 weeks. During establishment, plots received $\mathrm{N}$ at $29.4 \mathrm{~g} \cdot \mathrm{m}^{-2}$, distributed in six fertilizer applications. Fertilizer analysis was $16 \mathrm{~N}-2 \mathrm{P}-$ $7 \mathrm{~K}$, with micronutrients; $\mathrm{N}$ source was primarily isobutylidene diurea. Stolon encroachment and fire ants were controlled; no chinch bug activity was noticed. Plots were irrigated $8 \mathrm{~mm}$ every other night, decreasing during the winter to once per week, through Feb. 1988. When plots were nearly (mean $=97 \%$ ) covered with turf, soil was irrigated to saturation on 29 Feb. 1988 and the irrigation was then permanently suspended. Presence or absence of wilt was recorded at least three times per week, during the first 41 days after irrigation was suspended. Most plots were either entirely wilted or not wilted; in intermediate cases, the threshold for designating a plot wilted was when $80 \%$ or more of the canopy was wilted. Wilt was recorded on 16 days in the afternoon (between 1400 and $1700 \mathrm{HR}$ ) and 7 days in the morning (between 0800 and 0900 HR). Rain ( $24 \mathrm{~mm}$ ) on 10 Apr. 1988 stopped the progression of wilt. Frequency of wilt (as a percentage of days) was calculated for each plot; when a plot remained wilted on separated

Table 1.Wilted area of 20 St. Augustinegrass genotypes during brief (3- to 14-day) intervals of irrigation suspension in field plots at the Fort Lauderdale Research and Education Center during 3 years at two fertilization rates. Means of eight replications.

\begin{tabular}{|c|c|c|c|c|c|c|c|}
\hline \multirow[b]{5}{*}{ Genotype } & \multicolumn{7}{|c|}{ Wilted area (\% of canopy) } \\
\hline & \multicolumn{7}{|c|}{ Year } \\
\hline & \multicolumn{2}{|c|}{1987} & \multirow{2}{*}{\multicolumn{2}{|c|}{$\begin{array}{c}1988 \\
\text { Fertilization }\end{array}$}} & \multirow{2}{*}{\multicolumn{2}{|c|}{1989}} & \multirow[b]{3}{*}{ Mean } \\
\hline & \multirow[b]{2}{*}{ High } & \multirow[b]{2}{*}{ Low } & & & & & \\
\hline & & & High & Low & High & Low & \\
\hline \multicolumn{8}{|c|}{ Polyploids } \\
\hline Bitterblue & 9 & 1 & 7 & 0 & 6 & 0 & 4 \\
\hline Floratam & 30 & 13 & 2 & 1 & 0 & 0 & 8 \\
\hline FX-41 & 22 & 11 & 7 & 5 & 1 & 0 & 8 \\
\hline Polyploid mean & 20 & 8 & 5 & 2 & 2 & 0 & 6 \\
\hline \multicolumn{8}{|c|}{ Diploids } \\
\hline FX-305 & 28 & 11 & 25 & 5 & 17 & 4 & 15 \\
\hline FX-36 & 33 & 15 & 13 & 2 & 31 & 3 & 16 \\
\hline $\mathrm{FX}-22$ & 56 & 31 & 14 & 1 & 7 & 0 & 18 \\
\hline Seville & 47 & 21 & 19 & 3 & 19 & 0 & 18 \\
\hline FX-338 & 49 & 28 & 21 & 1 & 13 & 0 & 19 \\
\hline FX-28 & 45 & 32 & 26 & 3 & 17 & 1 & 21 \\
\hline FX-51 & 44 & 19 & 30 & 3 & 29 & 0 & 21 \\
\hline FX-234 & 66 & 36 & 18 & 0 & 11 & 0 & 22 \\
\hline FX-261 & 42 & 26 & 29 & 2 & 28 & 6 & 22 \\
\hline FX-148 & 38 & 22 & 33 & 5 & 36 & 5 & 23 \\
\hline FX-313 & 38 & 21 & 50 & 13 & 27 & 4 & 26 \\
\hline FX-332 & 77 & 39 & 26 & 1 & 14 & 0 & 26 \\
\hline FX-299 & 49 & 25 & 40 & 4 & 36 & 12 & 27 \\
\hline FX-29 & 62 & 46 & 32 & 1 & 19 & 6 & 28 \\
\hline FX-74 & 74 & 43 & 28 & 0 & 23 & 0 & 28 \\
\hline FX-281 & 77 & 49 & 25 & 3 & 14 & 11 & 30 \\
\hline Florida Common & 83 & 62 & 44 & 5 & 18 & 0 & 35 \\
\hline Diploid mean & 53 & 31 & 28 & 3 & 21 & 3 & 23 \\
\hline \multicolumn{8}{|c|}{ Statistics, genotype effect } \\
\hline$F_{(19,133 \text { d.f. })}$ & $14.04^{* * *}$ & $8.33^{* * *}$ & $12.46^{* * * *}$ & $2.84^{* *}$ & $9.73^{* * *}$ & $2.40^{*}$ & $4.75^{\text {*** }}$ \\
\hline $\mathrm{CV}$ & 36.9 & 56.3 & 85.4 & 206.5 & 120.7 & 438.1 & 70.4 \\
\hline $\mathrm{MSD}^{\mathrm{z}}$ & 16 & 14 & 23 & 7 & 29 & 23 & 5 \\
\hline \multicolumn{8}{|c|}{ Single-degree-of-freedom contrast, polyploid vs. diploid } \\
\hline $\mathrm{F}_{(1,7 \text { d.f. })}$ & $40.01^{* * *}$ & $39.08^{* * *}$ & $12.53^{* *}$ & $1.60^{\mathrm{Ns}}$ & $9.24^{*}$ & $3.48^{\mathrm{Ns}}$ & $23.19^{* *}$ \\
\hline
\end{tabular}

rain-free afternoons or mornings, it was assumed to have remained wilted during the intervening days. Canopy cover was evaluated 4 Mar. 1988, before wilt occurred, and 3 May 1988, after an added $63 \mathrm{~mm}$ of rain had fallen (since 10 Apr. 1988), and after surviving stolons had produced new leaves frequency of wilt, canopy loss means (differences in canopy cover before drought and after refoliation) for genotypes were fitted to frequency of wilt, by the Gompertz nonlinear model, using the NLIN procedure (SAS Institute, 1988). Roots were washed from five soil cores, $8.9 \mathrm{~cm}$ in diam. $\times 40 \mathrm{~cm}$ deep; extracted from surviving areas of 'Floratam' and 'FX33' plots; and roots were dried, weighed, and combined into deep $(20-40 \mathrm{~cm})$ and shallow $(0-20 \mathrm{~cm})$ subsamples.

Wilted area and canopy loss from permanent irrigation suspension (Expt. 3). Four cultivars, the polyploids $(2 n=27$ to 32$)$ 'Bitterblue', 'Floratam', and 'FX-10', and the diploid $(2 n=18)$ 'Jade', were planted as sod on 25 Mar. 1993. There were two adjacent areas: four replications in completely randomized blocks located in full sun, and eight replications under $73 \%$ neutral shadecloth. Plots were $1.2 \times 3.7 \mathrm{~m}$, without alleys. Plots were fertilized on 19 Apr. 1993 with $\mathrm{N}$ at $9.5 \mathrm{~g} \cdot \mathrm{m}^{-2}$ (refoliation). For visualization of the effect of in activated sewage sludge, analysis $6 \mathrm{~N}-1 \mathrm{P}-$ $0 \mathrm{~K}$. Plots were mowed at $76 \mathrm{~mm}$, once per week. Plots received irrigation or rain through 4 June 1993, sufficient to prevent permanent wilt. Irrigation was suspended thereafter. Plots were evaluated for wilted area, as a percentage of the canopy, through 22 June 1993. Wilted area was recorded on 10 days in the afternoon (between 1300 and $1745 \mathrm{HR}$ ) and 6 days in the morning (between 0830 and $0940 \mathrm{HR}$ ). Rain (40 mm) on 24 June 1993 stopped the progression of wilt. Wilted area was averaged for each plot over 16 recordings. Canopy loss was evaluated on 1 July 1993, following a week with $47 \mathrm{~mm}$ rain, and after surviving areas had refoliated. For visualization of the effect of wilted area, canopy losses for each plot were fitted to wilted area, by the Gompertz nonlinear model, using the NLIN procedure (SAS Institute, 1988).

\section{Results and Discussion}

The soil was well-drained sand overlying a wet subsoil. For example, in the top $0.70 \mathrm{~m}$, the water-holding capacity was a maximum of only $45 \mathrm{~mm}$ retained following a saturating rain. The maximum soil moisture depletion (difference between saturation and drought) was $24 \mathrm{~mm}$ ( $2.1 \%$ by soil dry weight). Between 0.75 - and 1-m depth, during seasonal drought, there was a minimum $52 \mathrm{~mm}$ water ( $11.1 \%$ by soil dry weight). The water table averaged $1.35 \mathrm{~m}$ deep, and was always $<1.6 \mathrm{~m}$. Associated with the water table was an irregular limestone substratum with solution holes (dissolved lacunae) extending below $1.5 \mathrm{~m}$, and projections extending to within $0.4 \mathrm{~m}$ of the land surface.

Wilted area during briefirrigation suspensions (Expt. 1). Genotypes varied $(P \leq 0.05)$ in the wilted area in all three years and under both fertilization rates (Table 1). High fertilization plots were more wilted $(P \leq 0.001)$ than were low fertilization plots, and were associated with larger genotypic differences, i.e., larger F values for genotypes. The largest genotypic differences occurred under high fertilization in 1987, when the wilted area was largest. Genotype $\times$ fertilization and genotype $\times$ year interactions were significant. Mean wilted area from 1987 through 1989 for polyploid St. Augustinegrasses 'Bitterblue', 'Floratam', and 'FX-41' was significantly less (6\%) than for any of the 17 diploids (23\%) (Table 1). Progressively more severe wilt in 'FX-313' was attributed to parasitism by sting nematode (Belonolaimus longicaudatus Rau) occurring by July 1988 , up to 92 nematodes $/ 100 \mathrm{~cm}^{3}$ soil. Other grasses did not show the symptoms of sting nematode infestation, e.g., reduced quality ratings, lack of response to fertilization, and loss of canopy (Busey et al., 1991). Irrigation suspensions were too brief to cause canopy loss.

Frequency of wilt and canopy loss from permanent irrigation suspension (Expt. 2). Drought was severe; $31 \mathrm{~mm}$ rain occurred during 41 days drought, compared with 120 mm expected evapotranspiration (derived from Stewart and Mills, 1967). Individual plots at 
first wilted temporarily between 1400 and $1700 \mathrm{HR}$, regained turgidity the following morning, then wilted earlier and earlier on successive afternoons. Eventually some plots were still wilted at $0800 \mathrm{HR}$, became straw colored, and had brittle shoots. There was genotypic variation $(P \leq 0.001)$ in frequency of wilt (Table 2). During the first 41 days after irrigation was suspended, the most wilt-prone genotypes wilted on $60 \%$ to $70 \%$ of the days (mean of afternoons and mornings). In contrast, 'FX33 ' exhibited wilt on only $17 \%$ of the days. Mean frequency of wilt was $57 \%, 27 \%$, and $53 \%$ for diploids, African polyploids, and other polyploids, respectively. Following rain and refoliation of surviving areas, genotypes differed $(P \leq 0.001)$ in canopy cover ("after refoliation," Table 2). Mean canopy losses (differences in canopy cover before drought and after refoliation) were $51 \%, 4 \%$, and $47 \%$ for diploids, African polyploids, and other polyploids, respectively. Polyploids of African origin had a lower frequency of wilt $(P \leq$ $0.01)$ and less canopy loss than either diploids or other polyploids (Table 2). Canopy losses were positively associated with and predictable from frequency of wilt, based on the Gompertz model, $r^{2}=0.94$ (Fig. 1). Deep (20$40 \mathrm{~cm})$ and shallow $(0-20 \mathrm{~cm})$ dry root masses of 'Floratam' were $1100 \mathrm{~g} \cdot \mathrm{m}^{-3} \pm 800 \mathrm{SD}$ and $5000 \mathrm{~g} \cdot \mathrm{m}^{-3} \pm 1100 \mathrm{SD}$, respectively. Deep and shallow root dry masses of 'FX-33' were 1200 $\mathrm{g} \cdot \mathrm{m}^{-3} \pm 1200 \mathrm{SD}$ and $7700 \mathrm{~g} \cdot \mathrm{m}^{-3} \pm 2500 \mathrm{SD}$, respectively. With such large relative variability, quantitative comparison of deeper rooting among St. Augustinegrasses was not feasible. Nevertheless, a few roots of 'FX-10' were in the groundwater at 1.4-m depth, as well as penetrating a permanently wet marl covering the limestone substratum. Plots were not all fully covered at the time of irrigation suspension, yet diploids suffered the worst canopy loss, despite their more complete establishment. This result was contrary to any expectation that incomplete establishment resulted in inadequate rooting.

Wilted area and canopy loss from permanent irrigation suspension (Expt. 3). In the

Table 2. Frequency of wilt (of 23 recordings) during 41 days of seasonal drought in 1988, and canopy cover before drought injury and after refoliation, of 25 St. Augustinegrass genotypes under permanent irrigation suspension in field plots at Fort Lauderdale Research and Education Center. Means of eight replications.

\begin{tabular}{|c|c|c|c|}
\hline \multirow[b]{2}{*}{ Genotype } & \multirow[b]{2}{*}{ Frequency of wilt (\%) } & \multicolumn{2}{|c|}{ Canopy cover (\%) } \\
\hline & & Before drought injury & After refoliation \\
\hline \multicolumn{4}{|c|}{ African polyploids } \\
\hline FX-40 & 20 & 99 & 99 \\
\hline FX-33 & 17 & 99 & 98 \\
\hline FX-43 & 25 & 100 & 98 \\
\hline FX-10 & 26 & 90 & 98 \\
\hline FX-14 & 19 & 99 & 96 \\
\hline FX-41 & 29 & 97 & 95 \\
\hline FX-1 & 29 & 99 & 92 \\
\hline FX-2 & 49 & 89 & 66 \\
\hline African polyploid mean & 27 & 96 & 93 \\
\hline \multicolumn{4}{|c|}{ Other polyploids } \\
\hline Bitterblue & 23 & 99 & 97 \\
\hline $\mathrm{FX}-5^{\mathrm{z}}$ & 26 & 100 & 94 \\
\hline $\mathrm{FX}-35^{\mathrm{z}}$ & 37 & 100 & 92 \\
\hline $\mathrm{FX}-11^{\mathrm{z}}$ & 46 & 98 & 90 \\
\hline $\mathrm{FX}-4^{\mathrm{z}}$ & 61 & 96 & 36 \\
\hline FX-703 & 65 & 93 & 33 \\
\hline Floratam & 68 & 97 & 29 \\
\hline $\mathrm{FX}-3^{\mathrm{z}}$ & 67 & 97 & 21 \\
\hline Floralawn & 68 & 93 & 14 \\
\hline $\mathrm{FX}-20^{\mathrm{z}}$ & 63 & 86 & 12 \\
\hline $\mathrm{FX}-89^{\mathrm{z}}$ & 62 & 90 & 9 \\
\hline Other polyploid mean & 53 & 95 & 48 \\
\hline \multicolumn{4}{|c|}{ Diploids } \\
\hline FX-305 & 43 & 100 & 81 \\
\hline FX-115 & 45 & 100 & 73 \\
\hline FX-130 & 59 & 100 & 61 \\
\hline FX-154 & 57 & 100 & 34 \\
\hline FX-332 & 67 & 100 & 31 \\
\hline FX-134 & 69 & 95 & 11 \\
\hline Diploid mean & 57 & 99 & 48 \\
\hline \multicolumn{4}{|c|}{ Statistics, genotype effect } \\
\hline$F_{(24,168 \text { d.f. })}$ & $19.52^{* * * *}$ & $3.51^{* * *}$ & $34.37^{* * *}$ \\
\hline $\mathrm{CV}$ & 26.3 & 6.4 & 27.1 \\
\hline MSD $^{y}$ & 10 & 6 & 15 \\
\hline \multicolumn{4}{|c|}{ Single-degree-of-freedom contrasts } \\
\hline Polyploid vs. diploid & $* * *$ & $* *$ & $* * *$ \\
\hline African vs. other polyploids & $* * *$ & NS & $* * *$ \\
\hline
\end{tabular}

'Seedlings from 'Floratam'.

${ }^{\mathrm{y}} \mathrm{MSD}$, minimum significant differences by the Waller-Duncan Bayesian $k$ ratio $t$ test, $k=100, P \approx 0.05$. NS, **, ***Nonsignificant or significant at $P \leq 0.01,0.001$, respectively. shade, 'Jade', a diploid, had more wilted area $(8 \% P \leq 0.05)$ than the three polyploid genotypes. 'Bitterblue' had $4 \%$ wilted area in the shade, which was more than for 'Floratam' or 'FX-10.' 'Floratam' and 'FX-10' averaged $2 \%$, and did not differ from each other. Wilted area in the sun area was $33 \%, 28 \%, 25 \%$, and $20 \%$ for 'Jade,' 'Bitterblue', 'Floratam', and 'FX-10,' respectively; only 'Jade' and 'FX10 ' differed $(P \leq 0.05)$. In the pooled analysis of shade and sun areas, 'Jade' was more wilted than all three polyploids, among which 'Bitterblue' had more wilted area than 'FX10 ' $(P \leq 0.05)$. Canopy loss, which occurred only in the sun, differed $(P \leq 0.01)$ among genotypes, $58 \%, 56 \%, 11 \%$, and $6 \%$, for 'Jade', 'Bitterblue', 'Floratam', and 'FX-10', respec-

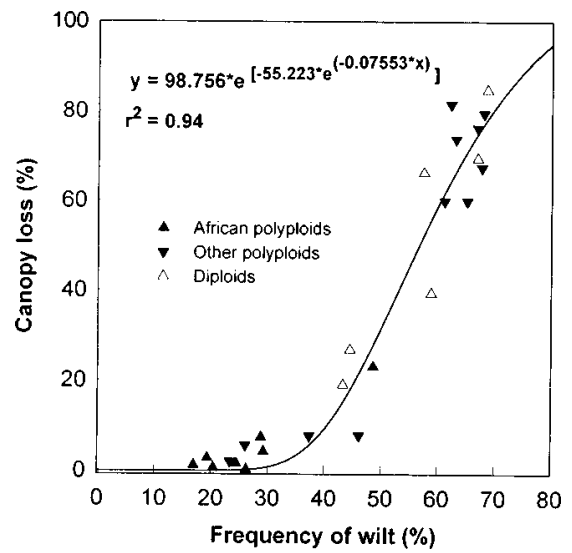

Fig. 1. Canopy loss following postdrought refoliation of $25 \mathrm{St}$. Augustinegrass genotypes, as a function of frequency of wilt during 41 days of seasonal drought (Expt. 2, Mar. to Apr. 1988). Canopy loss (difference in canopy cover before drought and after refoliation) for genotypes was fitted to frequency of wilt, by the Gompertz nonlinear model. Means of eight replications.

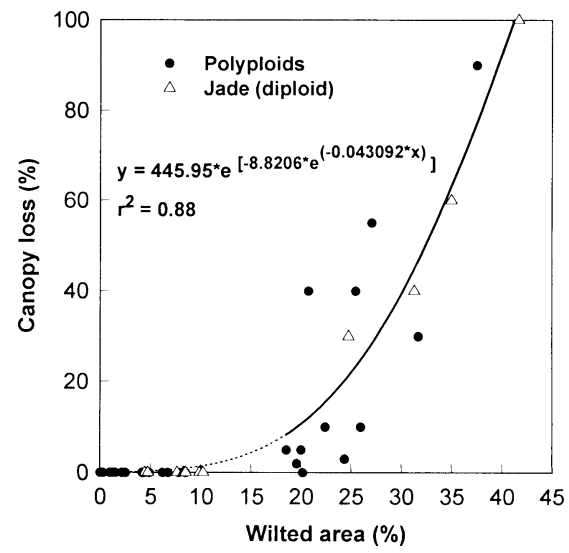

Fig. 2. Canopy loss following postdrought refoliation of four St. Augustinegrass genotypes, as a function of wilted area during 18 days of seasonal drought (Expt. 3, June 1993). Canopy losses (difference in canopy cover before drought and after refoliation) for plots were fitted to wilted area by the Gompertz nonlinear model. Points represent individual plots. 
tively. 'Jade' and 'Bitterblue' differed ( $P \leq$ $0.05)$ from 'Floratam' and 'FX-10' in canopy loss. Canopy loss was positively associated with and predictable from wilted area, based on the Gompertz model, $r^{2}=0.88$ (Fig. 2).

In each experiment, polyploid St. Augustinegrasses had less wilt (wilted area or frequency) compared with diploids, thus were relatively wilt avoidant. Amount of wilt was closely associated with canopy loss following permanent irrigation suspension, which demonstrates differential wilt avoidance in St. Augustinegrass germplasm. Wilt avoidance is a form of drought resistance, "a range of mechanisms whereby plants withstand periods of dry weather" (Paleg and Aspinall, 1981). Drought resistant plants, including grasses, are often resistant based on enhanced water absorption ability due to more effective root systems (Levitt, 1980). Among turfgrasses, tall fescue (Festuca arundinacea Shreb.), having a deeper root mass and deeper soil water extraction than Kentucky bluegrass (Poa pratensis $\mathrm{L}$ ), also has superior color retention during hot, dry summers (Sheffer et al., 1987). Rooting depth has been associated with turf quality of bermudagrass (Cynodon spp.) genotypes during drought stress in a greenhouse (Hays et al., 1991). Zoysiagrass (Zoysia spp.) genotypes' rooting depth in tubes is associated with area of green cover in the field under deficit irrigation (Marcum et al., 1995). Larger root length density in the deeper $(0.2$ to $0.6 \mathrm{~m})$ root zone is associated with less wilt and less leaf firing of tall fescue genotypes (Carrow, 1986).

The field site, with well-drained sand overlying a wet subsoil, permitted detection of wilt avoidance in St. Augustinegrass. The wet sub- soil and shallow $(1.35 \mathrm{~m})$ water table may have been a water source for wilt-avoidant St. Augustinegrass genotypes. The site characteristics are typical of southeastern Florida. For example, in monitoring wells throughout urbanized Dade and Broward counties, the mean depth of the Biscayne aquifer is $1.45 \mathrm{~m}$ and the average standard deviation across months is $0.06 \mathrm{~m}$ (values derived from Lietz et al., 1995). The water level is maintained throughout the region by lateral movement across permeable materials, supplied by rain and by canals connected to water conservation areas. The use of wilt-avoidant genotypes is a turf management tool to reduce the frequency of overhead irrigation while sustaining canopy survival during seasonal drought. This approach is worthwhile in level, humid areas, such as the coastal plains of the southeastern United States, where soil moisture is easily replenished. Wilt avoidance is highly associated with drought survival in St. Augustinegrass, and may serve as a tool in selecting drought-resistant germplasm.

\section{Literature Cited}

Atkins, C.E., R.L. Green, S.I. Sifers, and J.B. Beard. 1991. Evapotranspiration rates and growth characteristics of ten St. Augustinegrass genotypes. HortScience 26:1488-1491.

Beard, J.B. 1973. Turfgrass: Science and culture. Prentice-Hall, Englewood Cliffs, N.J.

Busey, P. 1986. Morphological identification of St. Augustinegrass cultivars. Crop Sci. 26:28-32.

Busey, P. 1990. Polyploid Stenotaphrum germplasm: Resistance to the polyploid damaging population southern chinch bug. Crop Sci. 30:588593.

Busey, P., R.M. Giblin-Davis, C.W. Riger, and E.I. Zaenker. 1991. Susceptibility of diploid St.
Augustinegrasses to Belonolaimus longicaudatus. Supplement to Journal of Nematology 23:604-610.

Carrow, R.N. 1986. Drought avoidance characteristics of diverse tall fescue cultivars. Crop Sci. 36:371-377.

Hays, K.L., J.F. Barber, M.P. Kenna, and T.G. McCollum. 1991. Drought avoidance mechanisms of selected bermudagrass genotypes. HortScience 26:180-182.

Johns, D., J.B. Beard, and C.H.M. van Bavel. 1983. Resistances to evapotranspiration from a St. Augustinegrass turf canopy. Agron. J. 75:419422.

Kneebone, W.R. and I.L. Pepper. 1982. Consumptive water use by sub-irrigated turfgrasses under desert conditions. Agron. J. 74:419-423.

Levitt, J. 1980. Responses of plants to environmental stresses. Vol. II: Water, radiation, salt, and other stresses. Academic, New York.

Lietz, A.C., T.E. Richards, and R. Krulikas. 1995. Water resources data Florida. Water year 1994. Vol. 2B. South Florida ground water. U.S. Geological Survey Water-Data Report FL-94-2B. U.S. Geological Survey Water Resources Division, Miami.

Marcum, K.B., M.C. Engelke, S.J. Morton, and R.H. White. 1995. Rooting characteristics and associated drought resistance of zoysiagrasses. Agron. J. 87:534-538.

Paleg, L.G. and D. Aspinall. 1981. The physiology and biochemistry of drought resistance in plants. Academic, Sydney, Australia.

SAS Institute. 1988. SAS/STAT user's guide, release 6.03 edition. SAS Inst., Cary, N.C.

Sheffer, K.M., J.H. Dunn, and D.D. Minner. 1987. Summer rooting response and rooting depth of three cool-season turfgrasses. HortScience 22:296-297.

Stewart, E.H. and W.C. Mills. 1967. Effect of depth to water table and plant density on evapotranspiration rate in southern Florida. Trans. ASAE 10:746-747. 